\title{
'n Behoefte-analise met die oog op die ontwerp van 'n Taal vir Spesifieke Doeleindes (TSD)-kursus vir leerderonderwysers met Afrikaans as tweede taal
}

\author{
Arné Greyling en Elbie Adendorff \\ Departement Afrikaans en Nederlands, Universiteit Stellenbosch, Suid-Afrika \\ E-pos: arne@sun.ac.za; elbie@sun.ac.za
}

\section{Opsomming}

Die implementering van 'n veeltaligheidsbeleid in Suid-Afrika vereis dat die onderrig en leer van Afrikaans as tweede taal, met spesifieke fokus op die onderrig van Afrikaans vir spesifieke doeleindes aan volwassenes (ook op universiteitsvlak), aandag geniet. Onderwysers en onderwysstudente moet daarop voorberei word om effektief onderrig te kan gee, aangesien daar van leerders verwag word om op 'n akademiese vlak met taal te kan omgaan. Die Nasionale Departement van Onderwys verwag onder meer van nuutgekwalifiseerde onderwysers om in die algemeen sowel as binne hul spesifieke vakgebiede effektief te kan kommunikeer aangesien onderwysers as tussengangers van leer optree. Die doel van hierdie artikel is om die spesifieke behoeftes van eerstejaar-onderwysstudente met Afrikaans as tweede taal te ondersoek met die doel om 'n taakgebaseerde Afrikaans vir spesifieke doeleindes-kursus te ontwerp. Sekere faktore moet in ag geneem word by die ontwerp van 'n sillabus, naamlik die kulturele, opvoedkundige en organisatoriese aspekte, die taalaanleerder, die onderwyser en die beskikbaarheid van onderrigmateriaal. 'n Behoefte-analise kan gebruik word om te verseker dat daar aan bogenoemde faktore aandag geskenk word met die ontwerp van 'n sillabus. Nog voordele wat behoefte-analises inhou, is dat onderrigmetodes kan verbeter, onderwysers kan aanpas by die verskillende taalaanleerders in hulle klasse en taalaanleerders deur die leerproses kan lei. Die artikel lewer verslag van 'n ondersoek oor die ontwerp van 'n Afrikaanse spesifiekedoeleindeskursus vir eerstejaar-onderwysstudente. Die spesifieke fokus is op die behoefte-analises wat onderneem is. 'n Reeks metodologiese stappe wat gevolg kan word in 'n behoefte-analise met die oog op kursusontwerp, tesame met die toepassing daarvan, word in die artikel aangebied.

Sleutelwoorde: Taal vir Spesifieke Doeleindes (TSD), behoefte-analise, taakgebaseerde metodologie, Afrikaanse tweedetaalverwerwing 


\section{A needs analysis with the aim of designing a Language for Specific Purposes (LSP) course for student teachers with Afrikaans as second language}

\section{Extended abstract}

The task-based approach ${ }^{1}$ in language teaching is seen as an effective method for the acquisition of a language as it offers the most opportunities for interaction and negotiation of meaning. The task-based approach is followed in the language acquisition modules, Afrikaans Language Acquisition 178 (Afrikaans for foreign language speakers) and Afrikaans Language Acquisition 188 (Afrikaans as a second language) that is presented by the Department of Afrikaans and Dutch at Stellenbosch University. The purpose of these language acquisition modules is to provide support to students by providing them with the skills and vocabulary to be able to communicate on generic academic and generic social levels. Although these modules focus on general language skills, a need exists for more specific courses, in other words, courses in language for specific purposes.

A requirement for enrolling in the course Afrikaans Language Acquisition 188 is that students must have passed Afrikaans First Additional Language at school. It is thus assumed that these students will already have good communication skills in Afrikaans. According to the distinction made by Cummins (2008) they already possess basic interpersonal communication skills (BICS) and must consequently develop cognitive academic language proficiency (CALP). These students do not need language acquisition classes, but rather language development classes. Courses for language for specific purposes and content based courses can be used for this purpose.

First year students of the Faculty of Education at Stellenbosch University take Afrikaans as a subject at the Department of Afrikaans and Dutch in the Faculty of Arts and Social Sciences. The Department of Afrikaans and Dutch divides the first year students into two groups: first language speakers of Afrikaans (students who passed Afrikaans as Home Language in grade 12) and second language speakers of Afrikaans (Students who passed Afrikaans as First Additional Language in grade 12). They are then respectively registered for Afrikaans and Dutch 178 or Afrikaans Language Acquisition 188.

All second year Education students, irrespective of their home language, enrol for the following modules: Afrikaans as language of teaching and learning (278 or 288) and Afrikaans (ED) 278. According to the Yearbook of the University of Stellenbosch (2013:71-74) the following aspects form part of these modules:

Afrikaans as language of teaching and learning:

Effective use of Afrikaans as a medium of instruction.

Speaking and listening for different purposes and target groups.

Reading for comprehension purposes to respond on a variety of texts.

Writing for a variety of purposes and target groups.

Suitable and effective use of language structures and conventions.

\footnotetext{
${ }^{1}$ Ellis (2003:351) defines the task-based approach as utilizing "tasks to provide free practice in the use of a specific linguistic feature that has been previously presented and practised in exercises".

${ }^{2}$ The abbreviation ED (Education) refers to modules that are specifically designed for Education students.
} 
Afrikaans (ED):

Approaches to language teaching, communicative language teaching.

Exploration of learning outcomes and assessment standards.

Visual and cultural literacy, text dynamics.

Introduction to assessment in language.

The home languages of students are not taken into consideration in the assessment opportunities for these modules. All students are expected to be able to use Afrikaans at a sufficient level especially with the aim of future teaching in Afrikaans.

Since South Africa is diverse in terms of language and culture, teachers (and student teachers) must be prepared that effective teaching is challenging as learners are expected to use language at a high academic level (Van der Walt and Ruiters 2011:96). Van der Walt and Ruiters (2011:96) emphasize that linguistic diversity, as found in Western Cape schools, has a direct influence on the learner's chances of success and education courses must prepare student teachers to be able to teach in these multilingual contexts. According to Van der Walt and Ruiters (2011:96) it is especially in the foundation and intermediate phases of teaching instruction where it is important for the teacher to be able to function in a multilingual context.

The Language Policy for Higher Education (2002) endorses multilingualism and language diversity in tertiary education. The issues relating to multilingualism in tertiary contexts and the design of vocational language teaching programs has not yet received enough attention in research. The teaching of languages includes courses for specific purposes to adult learners who have not received much attention in Afrikaans second language research. Therefore, this study on the needs analysis, which can serve as basis for the design of a vocational language teaching program for teaching students, has been undertaken.

The framework of the Language Policy for Higher Education (2002: 11) specifies the use of Afrikaans as a medium of academic expression and communication in higher education. It encourages the study of additional languages (including Afrikaans). Where students do not have a sufficiently advanced level of proficiency in the language of instruction, effective courses should be available to improve and develop students' language abilities and skills in the language of instruction. Jordan (1997), Van Dyk (2005) and Van Rensburg and Weideman (2002) show a direct relationship between academic language proficiency levels and successful study. Therefore, students must achieve a sufficient level of academic language proficiency in Afrikaans in order to be successful in their studies. This is especially important because of the double and parallel medium in which undergraduate teaching is received at several higher education institutions.

The purpose of this article is to address the specific needs of first year Education students with Afrikaans as a second language with the aim of designing a task-based course for Afrikaans for specific purposes. A needs analysis can be used to ensure that organisational, educational and methodological factors are attended to during syllabus design. More benefits of needs analysis include that teaching methods can improve, teachers can adapt to the different language learners in their classrooms, and language learners can be lead through the learning process. This article presents a series of methodological steps, together with the application thereof, that can be followed in a needs analysis with the eventual aim of course design. 
Keywords: Language for Specific Purposes (LSP), needs analysis, task based methodology, Afrikaans second language acquisition

\section{Inleiding}

Die aanleer van 'n tweede taal ${ }^{3}$ (wat ook die aanleer van derde en vierde tale insluit) is geen maklike taak nie en stel uitdagings aan die taalaanleerder - meer nog as dit geskied wanneer die taalaanleerder reeds 'n volwassene is. Sedert die sewentigerjare is daar groeiende belangstelling in navorsing oor tweedetaalverwerwing, veral op skoolvlak.

Die taakgebaseerde teorie het die laaste dekade as 'n invloedryke teorie na vore gekom as raamwerk vir navorsing oor tweedetaalverwerwing en -ontwikkeling (Adendorff 2012, Ellis 2003, Klapper 2003, Nunan 2004 en Skehan 1998). Die taakgebaseerde benadering word deur Ellis (2003) gesien as 'n ontwikkeling vanuit die kommunikatiewe benadering, waar die primêre funksie van taal interaksie en kommunikasie is. Volgens Littlewood (2004:324) vorm take die grondslag van die metodologie sowel as die eenhede waarvolgens kursusse georganiseer word. In die taakgebaseerde benadering word daar geglo dat taalverwerwing die effektiefste sal geskied wanneer kontekste geskep word waarin taalaanleerders die teikentaal kan oefen. In die taakgebaseerde benadering kan die taalaanleerder natuurlik die taal verwerf deur dit te gebruik in plaas van om die taal te probeer leer deur op die taalreëls en algemene linguistiese eienskappe daarvan te fokus.

Adendorff (2012:8) beweer dat die uitvoering van 'n behoefte-analise sentraal tot die taakgebaseerde benadering en taal vir spesifieke doeleindes (TSD) ${ }^{4}$ is. Taal vir spesifieke doeleindes is volgens Samuda en Bygate (2008:53) taalopleiding vir nie-taalspesialiste wat dit vir akademiese of professionele doeleindes benodig omdat dit as basis dien vir die spesifisering van die inhoud én om relevante take binne die spesifieke inhoude te ontwerp. Behoefte-analises word toenemend in sillabusontwerp gebruik.

In hierdie artikel word gekyk na hoe en tot watter mate behoefte-analises bydra tot die bepaling van die inhoud van 'n taalkursus vir spesifieke doeleindes vir Afrikaans-tweedetaalonderwysstudente. Dié studente benodig 'n eiesoortige sillabus omdat die aard van hulle kommunikasie ander eise stel as die generiese taalverwerwingskursusse. Daarom sal daar na die eienskappe van die spesifieke vaardighede wat die studente nodig het, in die behoefteanalises gekyk word.

Die artikel fokus eerstens op die konteks van die studie, wat die rasionaal daaragter duidelik maak en die doelwitte daarvan verskaf. Hierna vernou die fokus van die artikel na behoefteanalises en die tien stappe vir behoefte-analises, soos deur Brown (2009) geïdentifiseer, word op die teikengroep toegepas. 'n Gevolgtrekking wat na aanleiding van die behoefte-analise en die data wat daaruit verkry is, word ten slotte gegee.

\footnotetext{
${ }^{3}$ Tweedetaalverwerwing is volgens Gass en Selinker (1994) die oorkoepelende term wat gebruik word vir die proses van die aanleer van ' $n$ taal naas die eerste taal. Die terme addisionele taal en teikentaal word ook in die navorsingsliteratuur gebruik.

${ }^{4}$ Dit is 'n vertaling van die begrip "languages for specific purposes" of "LSP". Die afkorting "TSD" sal ter wille van stilistiese afwisseling gebruik word om na "taal vir spesifieke doeleindes" te verwys.
} 


\section{Konteks van die studie}

Die taakgebaseerde benadering in taalonderrig word as ' $\mathrm{n}$ effektiewe metode vir die aanleer van ' $n$ taal beskou omdat dit die meeste geleenthede tot interaksie en betekenisonderhandeling bied. Hierdie taakgebaseerde benadering word binne die Departement Afrikaans en Nederlands aan die Universiteit van Stellenbosch se taalverwerwingsklasse, naamlik Afrikaanse Taalverwerwing 178 (Afrikaans vir vreemdetaalstudente) en Afrikaanse Taalverwerwing 188 (Afrikaans as tweede taal) ${ }^{5}$, gebruik. Die doel van hierdie taalverwerwingsmodules is om studente by te staan om binne hul spesifieke fakulteite en kursusse op generies akademiese en generies sosiale vlakke in Afrikaans te kan kommunikeer. Alhoewel die bestaande modules op algemene taalvaardighede fokus, is daar behoefte aan meer spesifieke kursusse: kursusse met die oog op taal vir spesifieke doeleindes.

Omdat studente wat die module ATV 188 neem Afrikaans as Eerste Addisionele Taal op skool geslaag het, het hulle reeds goeie kommunikasievaardighede in Afrikaans. Volgens Cummins (2008) se onderskeid het hulle klaar basiese interpersoonlike kommunikasievaardighede (BIKV) en kognitiewe akademiese taalvaardighede (KATV) moet verder ontwikkel word. Hulle benodig nie taalverwerwingsklasse as sodanig nie, maar eerder taalontwikkelingsklasse. Hiervoor kan spesifiekedoeleindeskursusse of inhoudsgebaseerde kursusse gebruik word.

Die eerstejaarstudente van die Fakulteit Opvoedkunde van die Universiteit van Stellenbosch neem Afrikaans by die Departement Afrikaans en Nederlands van die Fakulteit Lettere en Sosiale Wetenskappe. Die Departement verdeel die eerstejaarstudente in Afrikaans eerstetaalsprekers (die studente het Afrikaans as Huistaal in graad 12 geslaag) en Afrikaans tweedetaalsprekers (die studente het Afrikaans as Eerste Addisionele Taal in graad 12 geslaag). Hulle word dan onderskeidelik verplig om Afrikaans en Nederlands 178 of Afrikaanse Taalverwerwing 188 te neem.

Alle tweedejaar-onderwysstudente neem saam die volgende Afrikaanse modules: Afrikaans as taal van onderrig en leer (278 of 288) en Afrikaans (OND) ${ }^{6} 278$. Hierdie modules behandel die volgende aspekte, soos omskryf in die Jaarboek van die Universiteit van Stellenbosch (2013:71-74):

Afrikaans as taal van onderrig en leer:

Doeltreffende gebruik van Afrikaans as voertaal en onderrigmedium.

Praat en luister vir verskillende doeleindes en teikengroepe.

Lees en kyk vir begrip om op 'n verskeidenheid tekste response te lewer.

Skryf vir 'n groot verskeidenheid doeleindes en teikengroepe.

Gepaste en doeltreffende gebruik van taalstrukture en -konvensies.

Afrikaans (OND):

Benaderings tot taalonderrig, kommunikatiewe taalonderrig.

Verkenning van leeruitkomste en assesseringstandaarde.

Visuele en kulturele geletterdheid, teksdinamika.

Inleiding tot assessering binne taal.

\footnotetext{
${ }^{5}$ Die afkorting "ATV" sal ter wille van stilistiese afwisseling gebruik word om na "Afrikaanse Taalverwerwing" te verwys.

${ }^{6}$ Die afkorting "OND" (Onderwys) word gebruik om na modules te verwys wat spesifiek vir onderwysstudente ontwerp is.
} 
In die assesseringsgeleenthede in hierdie modules word 'n student se moedertaal nie in ag geneem nie. Alle studente behoort op 'n voldoende vlak met Afrikaans as taal te kan omgaan, spesifiek met die oog op moontlike onderrig in Afrikaans.

Aangesien Suid-Afrika divers is ten opsigte van kultuur en taal, moet onderwysers (en onderwysstudente) daarop voorbereid wees dat effektiewe onderrig uitdagend is, omdat van leerders verwag word om met taal op 'n hoë akademiese vlak om te gaan (Van der Walt en Ruiters 2011:96). Van der Walt en Ruiters (2011:96) beklemtoon dat linguistiese diversiteit, soos gevind kan word in Wes-Kaapse skole, 'n direkte invloed op leerders se kanse op sukses het en dat onderwyskursusse leerder-onderwysers daarop moet voorberei om in veeltalige kontekste onderrig te kan gee. Volgens Van der Walt en Ruiters (2011:96) is dit veral in die grondslag- en intermediêre onderrigfases waar dit vir die onderwyser belangrik is om in ' $\mathrm{n}$ veeltalige konteks te kan funksioneer. Dit is twee van die onderrigfases waarvoor onderwysstudente in graadprogramme opgelei word en daarom moet onderwysstudente in hierdie twee onderrigfases se taalopleiding van so 'n aard wees dat hulle suksesvol in 'n veeltalige konteks sal kan funksioneer.

Die Raamwerk van die Taalbeleid vir Hoër Onderwys (2002: 11) spesifiseer die gebruik van Afrikaans as 'n medium van akademiese uitdrukking en kommunikasie in hoër onderwys. Dit moedig verder die studie van addisionele tale (wat Afrikaans insluit) aan. Waar studente nie 'n genoegsaam gevorderde taalvaardigheidsvlak in die taal of tale van onderrig het nie, behoort doeltreffende kursusse beskikbaar te wees om studente se taalvermoëns en taalvaardighede in die taal of tale van onderrig te ontwikkel. Jordan (1997), Van Dyk (2005) en Van Rensburg en Weideman (2002) wys daarop dat studente 'n genoegsame vlak van akademiese taalvaardigheid in Afrikaans moet bereik ten einde suksesvol te kan wees in hul studies. Dít is veral belangrik weens die dubbel- en parallelmedium waarin onderrig voorgraads by etlike hoëronderwysinstellings ontvang word.

Die onderrig van tale sluit kursusse vir spesifieke doeleindes aan volwasse leerders in. Daar word tans min of geen wetenskaplike navorsing oor die onderrig en leer van Afrikaans as tweede taal vir spesifieke doeleindes binne die universiteitskonteks binne die raamwerk van die taakgebaseerde benadering onderneem. Die studie na die behoefte-analise, wat as basis kan dien vir die ontwerp van ' $n$ beroepsgerigte taalonderrigprogram vir onderwysstudente, is om hierdie rede onderneem.

Die tien stappe in 'n behoefte-analise, soos deur Brown (2009) geïdentifiseer, word vervolgens uiteengesit en toegepas.

\section{3. 'n Toepassing van die metodologiese stappe van 'n behoefte-analise}

Die fokus van hierdie afdeling is die metodologiese stappe wat deel vorm van 'n behoefteanalise. Daar word eerstens inligting verskaf oor wanneer die spesifieke behoefte-analise gedoen is en wie die teikengroep is. Hierna word die navorsing van Brown (2009) toegepas op die behoefte-analise.

Behoefte-analises hou verskeie voordele in vir die onderrig en leer van tale, soos die verbetering van onderrigmetodes en die aanpassing van kursusmateriaal by spesifieke groepe. 'n Behoefte- 
analise word gesien as die eerste stap in die kursusontwerpproses, aangesien dit geldigheid aan enige daaropvolgende aktiwiteite verleen.

Een van die eerste vrae wat gevra word, is wanneer 'n behoefte-analise onderneem moet word. Dit kan óf voor die aanvang, reg aan die begin, gedurende óf aan die einde van 'n kursus gedoen word. Robinson (1991:15) is van mening dat 'n behoefte-analise grootliks voor die aanvang van 'n kursus gedoen moet word terwyl West (1994) daarop dui dat dit standaardpraktyk is om deurlopend ' $n$ behoefte-analise te doen sodat dit ' $n$ aanhoudende proses in plaas van 'n eenmalige ondersoek word. Die Afrikaanse Taalverwerwing 188-module maak gebruik van 'n deurlopende behoefte-analise, aangesien dit die meeste geleenthede vir die herevaluering van taalaanleerders se behoeftes bied.

In bogenoemde module word aan die begin van die akademiese jaar 'n vraelys aan studente gegee waarin vrae gevra word om hul behoeftes te bepaal. Die studente se skooluitslae sowel as die resultate van die taalplasingstoetse wat hulle voor die aanvang van die akademiese jaar skryf, is gebruik. Aan die begin van die tweede semester lewer die studente kortliks verslag van hoe die module tot dusver aan hulle behoeftes voldoen het of nie en op watter behoeftes daar nog gefokus moet word. Ongestruktureerde onderhoude word met individuele studente gevoer. Indien nodig word aanpassings aan die sillabus gemaak. Aan die einde van die jaar voltooi die studente weer 'n vraelys om te bepaal tot watter mate die module aan hul behoeftes voldoen het of nie.

Die stappe wat gevolg is in hierdie behoefte-analise word vervolgens bespreek.

\subsection{Die metodologiese stappe vir die uitvoer van 'n behoefte-analise}

Deur die navorsing van Schutz en Derwing (in Brown 2009), Jordan (1997) en Graves (2000) te kombineer, identifiseer Brown (2009:270) tien metodologiese stappe in 'n behoefte-analise, wat vir hierdie artikel toegepas is [AG - eie vertaling]:

Tabel 1: Tien stappe van behoefte-analise

\begin{tabular}{|l|}
\hline Stappe \\
\hline A Voorbereiding om 'n behoefte-analise te doen \\
\hline 1 Definieer die doel van die behoefte-analise \\
\hline 2 Beperk die omvang van die teikengroep \\
\hline 3 Besluit op benaderings en sillabusse \\
\hline 4 Erken beperkinge \\
\hline 5 Selekteer data-insamelingsprosedures \\
\hline B Doen die behoefte-analise \\
\hline 6 Versamel data \\
\hline 7 Analiseer data \\
\hline 8 Interpreteer die resultate \\
\hline C Gebruik die resultate van die behoefte-analise \\
\hline 9 Bepaal die doelwitte \\
\hline 10 Evalueer en lewer terugvoer oor die behoefte-analise \\
\hline
\end{tabular}

Die toepassing van bogenoemde tien stappe van Brown (2009) op die spesifieke behoefteanalise, word vervolgens bespreek. 


\subsubsection{Voorbereiding om 'n behoefte-analise te doen}

\subsubsection{Definieer die doel van die behoefte-analise}

As gevolg van die linguistiese diversiteit wat in Suid-Afrikaanse skole voorkom, moet onderwysers toegerus wees om in veeltalige kontekste onderrig te kan gee. Die behoefte vir die verdere ontwikkeling van Afrikaans as tweedetaal by Engelssprekende eerstejaaronderwysstudente is veral groot aangesien daar vanaf die tweede jaar in sommige onderwyskursusse geen onderskeid tussen twee groepe - Afrikaans eerstetaalsprekers en Afrikaans tweedetaalsprekers - getref word nie. In die tweede jaar van voorgraadse opvoedkundekursusse word daar van Afrikaans tweedetaalsprekers verwag om op dieselfde vlak met Afrikaans te kan omgaan as eerstetaalsprekers, spesifiek met die oog op moontlike onderrig in Afrikaans.

Die doel van die behoefte-analise is om die behoeftes van Engelssprekende eerstejaaronderwysstudente, te identifiseer met die oog op die ontwerp van 'n taakgebaseerde sillabus vir taal vir spesifieke doeleindes. Die behoefte-analise het verder ten doel om die eienskappe van die spesifieke vaardighede wat die eerstejaar-onderwysstudente binne hul teikenberoepe sal benodig, te identifiseer en te beskryf.

\subsubsection{Bepaal en beperk die teikengroep}

Die omvang en skaal van die behoefte-analise het te make met hoe breed die bestek daarvan is. 'n Behoefte-analise wat deel van 'n taaloudit vorm, sal op 'n baie groter skaal gedoen word as byvoorbeeld een wat slegs ten doel het om die behoeftes van 'n sekere groep studente by ' $n$ spesifieke leerinstelling te bepaal. Brown (2009:273) is van mening dat behoefte-analises in teorie op ' $n$ internasionale, nasionale, provinsiale of program- of klaskamervlak gedoen kan word, maar dat dit meer algemeen op 'n plaaslike vlak plaasvind.

Die skaal van die behoefte-analise wat tydens hierdie studie onderneem is, is beperk tot inligtingsbronne wat betrekking het op die doel van die studie. Onderwysstudente wat die module ATV 188 neem, het die belangrikste rol gespeel. Die groep het bestaan uit sowat 70 studente. Alhoewel die studente se behoeftes die primêre fokus van die behoefte-analise uitmaak, is daar ook na hulle verwagting oor hul toekomstige beroep gekyk. Literatuurbronne wat deur die Nasionale Departement van Onderwys aan onderwysers beskikbaar gestel word rakende die kurrikulum en die onderrig daarvan, sowel as ander beleidsdokumente wat deur die Departement van Onderwys opgestel is, is gebruik. Hieruit is teikentaalgebruiksituasies, soos byvoorbeeld die bywoon van vergaderings, die oordrag van kennis, gesprekke met ouers en die opstel en nasien van toetse, geïdentifiseer.

\subsubsection{Besluit op benadering en sillabus}

'n Benadering verwys, volgens Brown (1995:5), na die wyse waarop dít wat deur die taalaanleerder geleer moet word en hoe dit geleer moet word, beskryf word. Daar is besluit om die taakgebaseerde benadering te volg. Vervolgens moet die beperkings ten opsigte van die behoefte-analise in ag geneem word. 


\subsubsection{Erken beperkings}

Volgens Brown (2009:275) het die tekorte of beperkings binne 'n behoefte-analise dikwels te doen met die situasie eerder as met die taal. Singh (in Brown 2009:275) verskaf 'n uitgebreide lys van verskillende tipes tekorte wat almal te make het met die situasie wat 'n impak kan hê op die behoefte-analise: die geskiktheid van die sillabus, die administratiewe houdings teenoor tweede- of vreemdetaalonderrig en -leer, die beskikbaarheid van oudiovisuele hulpmiddele, die grootte van die klas, regeringstaalbeleide, beskikbaarheid van tyd vir die doen van 'n behoefteanalise, departementele organisasie, relevansie van vreemde- of tweedetaalleer tot ander vakke, skedulering, die samelewing se algemene houding teenoor die aanleer van 'n vreemde- of tweedetaal en die status van onderwysers sowel as die status van leerinstellings. Van hierdie beperkings is ook ervaar in die breë studie.

Aangesien daar reeds 'n algemene taalkursus (ATV 188) bestaan wat deur die eerstejaaronderwysstudente, sowel as studente uit ander graadprogramme en fakulteite, geneem word, is dit moeilik om die instelling van 'n kursus wat spesifiek op die behoeftes van die onderwysstudente gerig is, te regverdig. Alhoewel die doel van die breë studie is om so 'n spesifieke kursus te ontwerp, is die uiteindelike implementering daarvan die ideaal. As gevolg van 'n tekort aan hulpbronne (personeel en tyd) sowel as institusionele, departementele en administratiewe reëls sal die werklike situasie waarskynlik slegs toelaat dat sommige van die idees en take wat deel sou vorm van 'n sillabus vir onderwysstudente geïnkorporeer word by die algemene taalkursus.

Brown (2009:275) identifiseer verdere beperkings wat te make het met die onderwysers in terme van hul opleiding, kwalifikasies, taalvaardigheid, vaardighede, ondervinding, taal, motivering, ensovoorts. Hy is van mening dat die onderwysers se bereidwilligheid om tydens 'n behoefte-analise saam te werk een van die belangrikste faktore is wat die sukses daarvan beïnvloed. Sommige van die bogenoemde beperkinge is ervaar tydens die uitvoer van die behoefte-analise vir hierdie artikel.

In die ATV 188-module bied tutors die kleiner groepklasse aan terwyl die dosent drie weeklikse hooflesings aanbied. Nagraadse studente aan die Departement Afrikaans en Nederlands doen vanaf hul honneursjaar aansoek om tutors te wees. Dit gebeur dikwels dat tutors wat 'n groter belangstelling in letterkunde as taalkunde het, dit uitdagend vind om taalverwerwingsklasse aan te bied, aangesien hul belangstelling nie daarin lê nie en omdat die nodige taalkennis, onderrigvaardighede en motivering dikwels ontbreek. Nog 'n beperking is weens die klein ouderdomsverskil tussen tutors en studente. Studente is dikwels slegs twee tot drie jaar jonger as die tutors en dit veroorsaak dat tutors kan sukkel om outoriteit in die klaskamer te handhaaf. Daar is selfs gevalle waar die studente ouer as die tutors is en dit kan tot ongemaklike situasies lei veral wanneer die ouer studente voel dat die jonger tutor nie oor die nodige kennis beskik nie.

Ander beperkinge het te doen met die taalaanleerders self, byvoorbeeld hulle huistaal, taalagtergrond, ouderdom, akademiese status, taalvaardigheidsvlak, ensovoorts. Die onderwysstudente wat registreer vir die module ATV 188 is uiters divers in terme van hul herkoms en taalvaardigheidsvlakke. Alhoewel al die ingeskrewe studente Afrikaans as eerste addisionele taal op skool geslaag het, beteken dit nie dat hulle almal oor dieselfde taalvaardigheidsvlakke beskik nie. Daar is dikwels in een klas studente wat skaars Afrikaans kan praat tesame met studente wat so vlot is in Afrikaans dat dit voorkom asof dit hul moedertaal kan wees. Studente 
wat minder taalvaardig is, voel dikwels geïntimideer deur die studente wat byna vlot Afrikaans kan praat. Dit lei daartoe dat studente bang of skaam is om antwoorde in die klas te gee of om hul opinies te lug of hulp te vra omdat hulle bang is dat hulle foute sal maak. Dit is verder geweldig uitdagend om kursusmateriaal op so 'n wyse aan te pas dat die meer gevorderde studente geïnteresseerd bly terwyl die minder gevorderde studente die werk kan verstaan. Nog 'n beperking wat in ag geneem moes word, is dat hulle nie almal dieselfde beroepsdoelwitte het nie. Die studente wat grondslagfase onderwysers wil word, is van mening dat hulle taalvaardighede in Afrikaans nie op dieselfde vlak hoef te wees as dié van die onderwysstudente wat in die intermediêre- of seniorfase onderwys wil gee nie.

\subsubsection{Selekteer data-insamelingsprosedure}

Daar bestaan verskillende metodes om data in te samel. Die data-insamelingsprosedures moet vir die spesifieke situasie geskik wees, leerdergesentreerd, sistematies en prakties wees én goeie resultate kan lewer.

'n Onderskeid word getref tussen data-insamelingsprosedures wat in kwalitatiewe navorsing gebruik word en dié wat in kwantitatiewe navorsing gebruik word. Die behoefte-analise wat vir hierdie artikel onderneem is, het gebruik gemaak van kwalitatiewe data wat verkry is deur vraelyste aan taalaanleerders te gee. Daar is ook na die navorsingsliteratuur gekyk om moontlike teikensituasies vir die teikengroep te identifiseer.

Die volgende stap is om na aanleiding van die gekose data-insamelingsprosedure die data te begin versamel. Vervolgens word die verskillende tipes inligting wat ingesamel kan word, bespreek.

\subsubsection{Uitvoer van die behoefte-analise}

\subsubsection{Versamel data}

Die data-insamelingsproses vir die teikengroep het plaasgevind deur middel van 'n vraelys wat aan die begin van die akademiese jaar aan alle ingeskrewe studente vir die module ATV 188 gegee is. Hierdie module word deur studente uit verskillende fakulteite en departemente geneem maar die meerderheid van hulle is eerstejaar -onderwysstudente (BEd-studente). Nadat die vraelyste ingevul is, is dit volgens die kursusse waarvoor die studente ingeskryf het, gesorteer. Slegs die vraelyste van die onderwysstudente is vir hierdie artikel gebruik.

Oopeindevraelyste is gebruik om navraag te doen oor die studente se ervaring van Afrikaans op skool, hoe hul gevaar het in dié vak in Graad 12, hoekom hulle die module neem en wat hul verwagtinge rondom die module is. Die studente is gevra om hul taalvaardigheidsvlak aan te dui as uitstekend, baie goed, goed, swak en niebestaande. Opsommend het die vraelyste op vyf hoofareas gefokus, naamlik die student se agtergrond, die rede waarom die module gevolg word, die belangrikheid van spesifieke taalvaardighede in die persoonlike, akademiese en professionele domeine, 'n analise van die student se taalvermoëns volgens die Europese Referensiekader (2001) se selfanalitiese tabel en laastens 'n aanduiding van hoeveel aandag spesifieke taalvaardighede in die klas moet geniet. Verskillende behoeftedomeine is geïdentifiseer, soos byvoorbeeld akademiese taalvaardigheid, professionele taalvaardigheid, 
gemeenskapstaalvaardigheid, informele sosiale kontaksituasies, formele sosiale kontaksituasies, en so meer. Behalwe vir die vraelyste wat voor die module aan die studente gegee is, is daar ook aan die einde van die akademiese jaar vraelyste aan hulle gegee om terugvoer te kry. Hierin is vrae gevra oor of daar aan hulle verwagtinge in die module voldoen is, watter aspekte hulle geniet het of nie geniet het nie, watter wenke gegee kan word om die module te verbeter, of die huiswerk en assessering van die module billik geskied het en of die module relevant binne die studente se studierigting was.

As deel van die bestudering van literatuur tydens die behoefte-analise, is na materiaal waarmee onderwysers daagliks by die skool in aanraking kom, gekyk. Voorbeelde hiervan is riglyne wat deur die Departement van Onderwys aan onderwysers verskaf word ten opsigte van die kurrikulum en die onderrig daarvan, handboeke, korrespondensie en nuusbriewe. Die doel van die literatuurstudie was om ondersoek in te stel na tipiese taalgebruiksituasies waarin onderwysers hulself dikwels bevind. Dit het ten doel gehad om woordeskat waaroor onderwysers moet beskik, te identifiseer.

\subsubsection{Analiseer die data}

Brown (2009:281) is van mening dat die meerderheid behoefte-analises kwantitatiewe data tot gevolg het en dat daar seker gemaak moet word dat die data betroubaar, geloofwaardig, bevestigbaar en oordraagbaar is. In hierdie geval is gebruik gemaak van oopeindevraelyste wat kwalitatiewe data tot gevolg gehad het. Daar is van genoegsame bronne gebruik gemaak om betroubaarheid te verseker. Vervolgens word die data-analise bespreek.

\section{i. Data verkry uit vraelyste}

Dit was veral die vrae wat gehandel het oor die redes waarom die studente geregistreer het vir die module en hul verwagtinge omtrent die module, wat tot waardevolle antwoorde gelei het. Eersgenoemde vraag het onder andere hierdie antwoorde tot gevolg gehad [ons vetdruk]:

- "To understand the language better so that one day I will be able to approach kids who speak either Afrikaans or English and communicate with them in their choice of language."

- "So I will be able to teach in Afrikaans."

- "I will need it in my career."

- "So that I can be completely bilingual and so that it will be better for me as a teacher."

- "As a teacher you need to be able to communicate in and understand Afrikaans to accommodate all the students. It is also good to be bilingual."

- "Afrikaans is part of my BEd course and I am not fluent in it, so I would like to improve so that I can teach it well."

- "Being English and Afrikaans has advantages."

- "Because I want to be a teacher so I have to learn how to teach it."

Uit bostaande antwoorde is dit duidelik dat die studente reeds met die begin van die module die verband tussen tweetaligheid en hul beroep raaksien.

Op die vraag omtrent die studente se verwagtinge omtrent die module, is die volgende antwoorde ontvang [ons vetdruk]: 
- "Hopefully I will improve in my reading and writing skills as well as communicating with Afrikaans speaking pupils."

- "I will improve my Afrikaans and learn how to teach it."

- "To learn more about the language and speak it fluently so that I can become a better educator.'

- "Improve Afrikaans so I can become fully bilingual to make campus life easier and to teach."

- "To improve my communication skills and knowledge of Afrikaans."

Uit bogenoemde antwoorde is dit duidelik dat daar ' $n$ definitiewe behoefte by die studente bestaan om effektief in Afrikaans te kan kommunikeer. Hierdie kommunikasiebehoeftes hou verband met hul toekomstige beroep, naamlik om onderrig te gee. Dit is duidelik dat die studente voel dat hulle nog nie op 'n vlak is waar hulle hulself as tweetalig kan beskryf nie, of gemaklik in Afrikaans kan kommunikeer nie. Dit is verder duidelik dat daar waarde aan tweetaligheid geheg word en dat dit as 'n voordeel gesien word.

Waardevolle data is uit die terugvoervraelyste wat aan die einde van die module aan studente gegee is, verkry. Wisselende antwoorde is veral ontvang op die vraag na wat die taalaanleerders se verwagtinge van die kursus was en of daar daaraan voldoen is [ons vetdruk]:

Positief:

- "Om my taalgebruik te verbeter en hoe om dinge te ontleed. Ja, dit het ek bereik."

- "I wanted to learn how to apply Afrikaans better, and that was achieved by this module."

- "Die basiese beginsels van Afrikaans te leer en ja, dit is bereik."

- "Om meer Afrikaans te leer en verbeter, ja dit is bereik."

- "Ek wou meer oor die taal leer, want ek het nie na die basis op skool geluister nie. Die verwagtinge is bereik."

- "Ek het dieselfde verwag as op skool. Dit was soms dieselfde, maar ek het ook baie meer geleer."

- "Ek het verwag om my taal te verbeter en om my Afrikaans praat te verbeter. Dit het ek bereik."

- "Ek het verwag om meer taalreëls te leer. Dit is bereik."

Negatief:

- "[My expectation was] to learn to teach foundation phase students the basics of Afrikaans. We just learnt matric work all over again."

- "I expected to learn to teach basic Afrikaans to primary school children. So no, they were not accomplished."

- "Om iets nuut te leer, maar het net weer goed geleer wat ek op skool geleer het."

- "[Ek het verwag] om Afrikaans beter te verstaan, skryf, en praat. Nee, dit is nie bereik nie."

Uit bostaande voorbeeldantwoorde is dit duidelik dat die onderwysstudente se verwagtinge van die module gewissel het. Alhoewel daar negatiewe antwoorde op hierdie vraag was, was die antwoorde oorwegend positief. Dit is duidelik dat die grootste verwagting van die studente was om hul taalvaardighede te verbeter; hieraan is voldoen. Die studente wat aangedui het dat hulle 
verwag het om te leer hoe om Afrikaans te onderrig, het aangedui dat daar nie aan dié verwagting voldoen is nie. Myns insiens moet die doel van die module aan die begin van die jaar aan die studente bekend gemaak word. Dit sal verhoed dat hulle aan die einde van die module voel dat hul verwagtinge nie bereik is nie, of dat hulle die verkeerde verwagtinge van die module sal ontwikkel.

Nog waardevolle data wat uit die terugvoervraelyste verkry is, is die skakeling tussen die gebruik en leer van Afrikaans en hul toekomstige beroepe. Die vraag is aan die studente gestel of die module relevant was binne hul studierigting. Hier volg 'n paar antwoorde wat ontvang is [ons vetdruk]:

\section{Positief:}

- “Ja, dis moeilik om 'n Suid-Afrikaanse onderwyser te wees sonder om Afrikaans te kan praat."

- "Ja, net as ek beplan om in Suid-Afrika skool te gee, anders nie."

- "Ja, ek sal miskien tweetalige kinders moet leer eendag."

- "Ja, dis goed vir 'n onderwyser om meer as een taal te praat en verstaan."

- "Ja, as ek 'n onderwyser wil word, moet ek die basiese beginsels van Afrikaans kan verstaan, veral die spel van woorde en taalreëls."

- "Ja, want as 'n kind nie verstaan wat jy sê nie, kan jy vir hulle verduidelik."

- 'Ja, ek is 'n onderwysstudent en al gaan ek in Engels skool gee, moet my gebruik van Afrikaans korrek wees."

Negatief:

- 'Nie regtig nie, as 'n onderwysstudent wil ek wiskunde en wetenskap onderrig, nie tale nie."

- "Nee, omdat ek nie beplan om eendag by 'n Afrikaanse skool te werk nie."

- "Nee, ek swot grondslagfase, dis nie nodig om Afrikaans te gee nie."

- "Nee, ek praat Engels en gaan klas gee in Engels. Ek sal nooit weer Afrikaans doen of praat nie!"

- "Nee, ek sal klein kinders onderwys en hierdie Afrikaans is te moeilik en ek sal dit nie gebruik nie."

- "No, I want to teach in English and I thought the level was too high for primary school kids."

- 'No, I want to teach grades 0-3. They wont need to know 'lydende en bedrywende'."

Veral die negatiewe antwoorde maak dit duidelik dat sommige studente sukkel om die verband tussen die module en hul toekomstige beroep te sien. Aangesien daar wel studente is wat die relevansie van Afrikaans vir hul toekomstige beroep raaksien, wil dit voorkom asof dit regdeur die module duideliker aan hulle gemaak moet word wat die doel en die relevansie van die module is. Dit kom voor asof die studente die persepsie het dat hulle in die module gaan leer hoe om die taal te onderrig, met ander woorde dat hulle inhoud gaan leer wat hulle weer net so kan oordra in hul toekomstige beroep. In 'n mate is dit waar aangesien die taalreëls en taaloefeninge, sowel as van die ander oefeninge wat in die module gedoen word (byvoorbeeld filmstudie) so oorgedra kan word. Dit moet egter duidelik gemaak word aan die studente dat die hoofdoelwit taalverwerwing is sodat hulle - as taalaanleerders - hul eie taalvaardighede 
moet verbeter en ontwikkel. Hierdie doelwit word wel deur sommige studente geïdentifiseer soos duidelik blyk uit bostaande positiewe antwoorde.

Die data wat uit die behoefte-analise verkry is, stem grootliks ooreen met die bevindinge van die studie deur Nakao (2011) gedoen, waar daar gekyk is na Japannese onderwysstudente se sienings en bekommernisse rondom kommunikasie in Engels in hul toekomstige beroep. Nakao (2011:578) het gebruik gemaak van vraelyste wat aan die begin van 'n taalkursus aan studente gegee is. Hierdie vraelyste het gefokus op studente se houdings, vrese en bekommernisse rondom Engels en die moontlikheid daarvan om in Engels onderrig te moet gee. Uit die analise van Nakao (2011:579) se resultate is dit duidelik dat die deelnemers aan sy studie kommunikasie in die teikentaal as die belangrikste vaardigheid wat hulle sal benodig, beskou.

\section{ii. Data verkry uit literatuurstudie}

Die fokus van die literatuurstudie was om kommunikasiesituasies te identifiseer waarin die studente hulleself as onderwysers sal bevind. In die literatuurstudie het die bronne wat deur die Nasionale Departement van Onderwys aan onderwysers verskaf word veral waardevolle inligting gebied. In die dokument, Draft policy on the minimum requirements for teacher education qualifications selected from the Higher Education Qualifications Framework (HEQF) wat in 2010 vrygestel is, word sewe rolle geïdentifiseer wat deur onderwysers vervul moet word. Hierdie rolle is eerstens as spesialis van 'n vakgebied of dissipline, as 'n tussenganger vir leer, as 'n kursus- en materiaalontwerper, as leier, administreerder en bestuurder, as navorser en lewenslange leerder, as assessor en laastens as berader en lid van 'n gemeenskap. Binne die Suid-Afrikaanse konteks moet onderwysers hierdie verskillende rolle kan vervul deur gebruik te maak van beide Afrikaans en Engels.

In die HEQF (2010:55) word 'n reeks minimum vaardighede en eienskappe waaroor nuwe onderwysers moet beskik, voorgelê. Dit is veral vier van die vaardighede of eienskappe wat uitstaan en waarvoor die aanleer van Afrikaans belangrik is. Eerstens word daar verwag dat nuutgekwalifiseerde onderwysers die leerders in hul klas moet leer ken en bekend moet word met die wyses waarop die leerders leer, sowel as hul individuele behoeftes. Die onderwysers moet dan hul onderrigmetodes aanpas om aan die unieke behoeftes van die leerders te voldoen. Indien die leerders in 'n onderwyser se klas Afrikaanssprekend is en verkies om leermateriaal en onderrig in hul moedertaal te ontvang, moet die onderwyser daarby kan aanpas. Juis hierom is dit belangrik dat onderwysers binne 'n Suid-Afrikaanse konteks die geleentheid gebied moet word om tweetaligheid en meertaligheid te ontwikkel. Hierdie verwagting wat die Nasionale Departement van Onderwys aan nuutgekwalifiseerde onderwysers stel, stem ooreen met van die antwoorde wat reeds bespreek is wat uit die vraelyste verkry is op die vraag of die module relevant tot die taalaanleerders se toekomstige beroep is.

Nog 'n eienskap wat van nuwe onderwysers verwag word, is dat hulle moet weet hoe om effektief te kommunikeer in die algemeen sowel as binne hul spesifieke vakgebiede en om as tussenganger van leer te kan optree (Minister van Onderwys 2010:55). Anders as wat die verwagting van sommige studente is, soos duidelik blyk uit die antwoorde, sal hierdie kommunikasie nie noodwendig in die moedertaal van die onderwyser plaasvind nie. Dit is belangrik dat nuutgekwalifiseerde onderwysers daarop voorberei word dat hulle moontlik in Afrikaans sal moet kommunikeer, ook ten opsigte van hul vakgebied, selfs al is hulle nie taalonderwysers nie. Die moontlikheid kan bestaan dat onderwysers wat gekwalifiseerd is om 
byvoorbeeld wiskunde en wetenskap te gee, hierdie vakke in Afrikaans - die tweedetaal van die onderwyser - sal moet aanbied of dit moontlik in Afrikaans sal moet verduidelik. Hierdie is in teenstelling met van die verwagtinge wat in die vraelyste deur die studente uitgespreek is.

Die derde verwagting wat die Departement van Onderwys (2010) van nuutgekwalifiseerde onderwysers het, is dat hulle oor 'n hoë vlak van geletterdheid, syfer- en rekenaarvaardighede moet beskik. Daar word nie gespesifiseer dat hierdie vaardighede slegs in die moedertaal van die onderwysers moet wees nie - daar kan aangeneem word dat nuutgekwalifiseerde onderwysers oor 'n hoë geletterdheidsvlak in Afrikaans moet beskik.

Laastens word daar van nuwe onderwysers verwag om die diversiteit in die Suid-Afrikaanse konteks te verstaan om sodoende onderrig op so 'n wyse te kan gee sodat alle leerders ingesluit word. Die onderwysers moet leerders se leer- en sosiale probleme kan identifiseer om sodoende in samewerking met professionele dienste dié probleme te kan oplos. Om hierdie probleme te kan identifiseer, is dit belangrik dat onderwysers op so 'n wyse met die leerders kommunikeer sodat die leerders gemaklik sal voel om met die onderwysers oor hul probleme te praat. Hierdie kommunikasie sal dikwels in die moedertaal van die leerder geskied. Dit is belangrik dat onderwysers twee- of meertalig moet wees om sodoende suksesvol met leerders in hierdie tipe situasies te kan kommunikeer.

Uit bostaande bespreking is dit duidelik dat twee- of meertaligheid en taalvaardighede in Afrikaans baie belangrik is en dat die Nasionale Departement van Onderwys dit ook as belangrik ag. Dit is verder duidelik dat daar 'n behoefte is vir 'n taalkursus wat toekomstige onderwysers sal voorberei vir hul teikenberoep om sodoende te kan voldoen aan die verwagtinge wat aan hulle gestel word deur hul toekomstige werkgewers.

$\mathrm{Na}$ aanleiding van die inligting verkry uit die vraelyste en die literatuurstudie, is teikenkommunikasiesituasies soos die opstel en nasien van toetse, die bywoon van vergaderings en die afrig van sport en naskoolse aktiwiteite geïdentifiseer. Die interpretasie van data is die volgende stap in die behoefte-analiseproses.

\subsubsection{Interpreteer die resultate}

Dit is deurslaggewend dat die data wat ingesamel is op so 'n wyse ingesamel en geanaliseer word dat die interpretasie daarvan betroubaar, verifieerbaar, geloofwaardig en oordraagbaar is (Brown 2009:284). Vervolgens word wyses om betroubaarheid te verseker, bespreek voordat die interpretasie van die ingesamelde data gegee word.

Long en Crookes (1992) beklemtoon dat die analise van die taalaanleerders se behoeftes deur die sogenaamde triangulasie van bronne moet geskied. Volgens Long (2005:28) is triangulasie 'n proses waarbinne die navorser verskillende bronne, metodes, ondersoeke of teorieë en kombinasies daarvan met mekaar vergelyk. Bevestiging vir die gebruik van triangulasie word gevind in Kikuchi (2005:8), wat betoog dat dit belangrik is om verskillende navorsingsmetodes en -bronne in 'n behoefte-analise te gebruik. Kikuchi (2005:15) is voorts van mening dat beide kwalitatiewe onderhoude en direkte waarnemings van leerders in toekomstige ondersoeke gebruik moet word. 
Brown (2009:284) bied die volgende riglyne om die betroubaarheid van die interpretasie van data te verseker:

i. Die navorser moet sorgvuldig wees in die ordening van triangulasie sodat vooroordele van die verskillende databronne verminder en die sterkpunte vermeerder word.

ii. Die navorser moet versigtig wees in die ondersoek van hoe sy/haar vooropstellings die datakeuses kan beïnvloed.

iii. Die navorser moet daarvan bewus wees dat ongewone of treffende data hom/haar dalk kan aantrek.

Die resultate moet ondersoek word om nie net te kan sien hoe die verskillende bronne mekaar ondersteun nie, maar ook hoe hulle verskil. Hieruit kan belangrike inligting afgelei word. Juis hierom is die data wat verkry is uit die onderhoude sowel as die vraelyste en literatuurstudie, gekombineer om teikenkommunikasiesituasies te vorm. Hierdie lys van teikenkommunikasiesituasies is aan pretoetsing onderwerp om die geloofwaardigheid daarvan te verbeter deurdat dit aan belanghebbendes gegee is en die terugvoer wat ontvang is, is dat dit ' $n$ korrekte weerspieëling is van die situasies waarin onderwysers hul dikwels bevind.

\subsubsection{Interpretasie van data}

Die onderstaande kommunikasiesituasies is geïdentifiseer na aanleiding van die bronne en die bestudering van die verskillende tekste waarmee onderwysers in aanraking kom: onderwyseronderwyser-kommunikasie, onderwyser-leerder-kommunikasie, onderwyser-ouer-kommunikasie en onafhanklike-onderwyser-kommunikasie. ${ }^{7}$ Die sewe rolle van onderwysers wat deur die Departement van Onderwys geïdentifiseer is, is in ag geneem en word in tabel 2 voorgestel:

Tabel 2: Interpretasie van data verkry uit vraelyste en onderhoude

\begin{tabular}{|l|l|l|}
\hline Tipe kommunikasie & $\begin{array}{l}\text { Geïdentifiseerde rol wat } \\
\text { onderwyser moet vervul }\end{array}$ & $\begin{array}{l}\text { Geïdentifiseerde } \\
\text { kommunikasiesituasie }\end{array}$ \\
\hline $\begin{array}{l}\text { Onderwyser-onderwyser- } \\
\text { kommunikasie }\end{array}$ & $\begin{array}{l}\text { Spesialis van 'n vakgebied } \\
\text { of dissipline }\end{array}$ & $\begin{array}{l}\text { Vergaderings } \\
\text { Kommunikasie in die } \\
\text { personeelkamer } \\
\text { Gesprekke met beamptes van die } \\
\text { provinsiale onderwysdepartement } \\
\text { Gesprekke met } \\
\text { vakhoofde/skoolhoofde }\end{array}$ \\
\hline $\begin{array}{l}\text { Onderwyser-leerder- } \\
\text { kommunikasie }\end{array}$ & $\begin{array}{l}\text { Tussenganger vir leer } \\
\text { Leier, administreerder en } \\
\text { bestuurder } \\
\text { Berader en lid van 'n } \\
\text { gemeenskap } \\
\text { Assessor }\end{array}$ & $\begin{array}{l}\text { Klasgee/oordra van kennis; } \\
\text { Handhawing van dissipline in die } \\
\text { klaskamer } \\
\text { Afrig van sport en na-skoolse } \\
\text { aktiwiteite }\end{array}$ \\
\hline $\begin{array}{l}\text { Onderwyser-ouer- } \\
\text { kommunikasie }\end{array}$ & gemeenskap & $\begin{array}{l}\text { Oueraande } \\
\text { Informele gesprekke na skool } \\
\text { Kommunikasie deur middel van } \\
\text { briewe en e-pos }\end{array}$ \\
\hline
\end{tabular}

\footnotetext{
${ }^{7}$ Laasgenoemde verwys na kommunikasiesituasies waarin onderwysers onafhanklik moet optree, byvoorbeeld voorbereiding vir klasse.
} 


\begin{tabular}{|l|l|l|}
\hline $\begin{array}{l}\text { Onafhanklike- } \\
\text { onderwyser- } \\
\text { kommunikasie }\end{array}$ & Kursus- & Voorbereiding vir 'n klas \\
& en materiaalontwerper & Opstel van rapporte \\
& Assessor & Skryf van vorderingsverslae \\
& Navorser en lewenslange & Merk van huiswerk, opstelle en \\
leerder & toetse \\
\hline
\end{tabular}

Bostaande teikensituasies is gebruik om dialoë te skryf wat gebruik word vir die ontwikkeling van klaskamertake (ook genoem pedagogiese take).

\subsubsection{Gebruik die resultate van die behoefte-analise}

\subsubsection{Bepaal die doelwitte}

Brown (1995:96) wys daarop dat die doelwitte die skakel is wat behoefte-analises met die res van die kurrikulum (materiaal-, assesserings-, onderrig- en programevaluering) koppel. Om die doelwitte te spesifiseer is 'n manier om dit wat uit die behoefte-analise afgelei is, toe te pas op die uiteindelike onderrig wat gegee gaan word.

Die doelwit van die studie is die ontwerp van 'n kursus vir Afrikaans vir spesifieke doeleindes vir eerstejaar-onderwysstudente binne die taakgebaseerde benadering. Die data wat uit die behoefte-analises verkry is, is gebruik om dialoë ${ }^{8}$ te skep wat binne die taakgebaseerde raamwerk deel vorm van take wat uiteindelik georden word om 'n sillabus te vorm. Die dialoë handel onder meer oor die gesprek tussen twee onderwysers oor 'n leerder se akademiese vordering, die gesprek tussen 'n skoolhoof en 'n onderwyseres oor die gedrag van 'n leerling, die bespreking tussen 'n vakhoof en onderwysers oor die beplanning van die eerste kwartaal se werk, die skryf van 'n Curriculum Vitae om vir onderwysposte aansoek te doen, 'n werksonderhoud van 'n pas afgestudeerde student, die raadpleging by 'n mede-onderwysstudent oor klasvoorbereiding en metodiek met die oog om leerders tydens die proeftydperk gemotiveerd te hou en die gesprek tussen twee jong onderwysers oor hulle betrokkenheid by naskoolse aktiwiteite. Dit wissel in kompleksiteit van eenvoudig na meer komplekse take en bied 'n outentieke weerspieëling van werklikewêreld-kommunikasie.

$\mathrm{Na}$ aanleiding van die data wat uit die behoefte-analise verkry is, kan die doelwit gestel word om 'n kursus te ontwerp wat sal voldoen aan beide die studente se behoeftes sowel as die behoeftes wat daargestel word deur hul toekomstige werkgewers en die Nasionale Departement van Onderwys. Die uiteindelike doelwit is om taalaanleerders voor te berei om effektief te kan kommunikeer in Afrikaans in die teikensituasies soos gelys word in tabel 3.4.

Die bepaling van doelwitte is die voorlaaste stap in die behoefte-analiseproses. Hierdie doelwitte word daarna geïmplementeer om sodoende óf 'n nuwe sillabus te skep, óf 'n bestaande sillabus aan te pas. Nadat ' $n$ behoefte-analise gedoen is, is dit belangrik om terugvoer te lewer daaroor.

\subsubsection{Evalueer en lewer verslag oor die behoefte-analise}

Na die afloop van 'n behoefte-analise kan 'n verslag geskryf word wat meer inligting oor die projek gee. Hierdie verslag sluit inligting in soos 'n beskrywing van die teoretiese en praktiese

\footnotetext{
${ }^{8}$ Hierdie dialoë verskyn in die Magistertesis deur Greyling (2014).
} 
konteks van die projek, die navorsingsmetodologie en prosedures wat gebruik is. Dit is nuttig om na afloop van 'n behoefte-analise verslag daaroor te lewer sodat dit opgeneem kan word in vaktydskrifte of joernale (Brown 2009:277). Hierdie artikel kan gesien word as 'n verslag en evaluering van die behoefte-analise wat as deel van die breë navorsing onderneem is.

\section{Slot}

Die doen van 'n behoefte-analise is nie iets wat lukraak plaasvind nie en onderwysers en kursusontwerpers word aangeraai om 'n sistematiese benadering daartoe te volg. Die riglyne wat Brown (2009:270-293) bied ten opsigte van die stappe wat gevolg kan word, vergemaklik die taak van die onderwyser of kursusontwerper.

Bostaande bespreking van hierdie tien stappe het dit duidelik gemaak dat daar verskeie benaderings bestaan rondom behoefte-analises ten opsigte van wanneer dit moet plaasvind, wie daarby betrokke gemaak moet word, uit watter raamwerk dit gedoen moet word en wat die doel daarvan sal wees. Die keuse van watter benadering om te volg word grootliks deur die teikengroep van die behoefte-analise bepaal.

'n Aspek wat duidelik na vore gekom het tydens die doen van die behoefte-analise, is die behoefte aan 'n Afrikaanse taalkursus wat spesifiek gerig is op onderwysstudente. Onderwysstudente word in hul onderskeie modules opgelei om eendag onderwys te gee. Die meerderheid van hulle vakke is beroepsgerig en hulle sukkel om die belangrikheid van 'n algemene taalkursus in te sien. Hierdie probleem kan opgelos word deur die instelling van 'n taalkursus wat op hulle spesifieke behoeftes sowel as die behoeftes en eise van hul toekomstige beroep gerig is.

\section{Bronnelys}

Adendorff. 2012. Kompleksiteit in taakgebaseerde onderrig en leer van Afrikaans as tweede taal binne universiteitskonteks. Ongepubliseerde PhD. Stellenbosch: Universiteit Stellenbosch.

Brown, J.D. 1995. The elements of language curriculum: A systematic approach to program development. New York: Heinle \& Heinle.

Brown, J.D. 2009. Foreign and second language needs analysis. In M.H. Long en C.J. Doughty (reds.). The handbook of language teaching. Chichester: Wiley-Blackwell. pp. 269-293.

Council for Cultural Co-operation. Education Committee. Modern Languages Division, Strasbourg. 2001. Common European framework of reference for languages: Learning, teaching, assessment. Cambridge: Cambridge University Press.

Cummins, J. 2008. BICS and CALP: Empirical and theoretical status of the distinction. In B. Street en N.H. Hornberger (reds.). Encyclopedia of language and education. New York: Springer Science \& Business Media LLC. pp. 71-83.

Ellis, R. 2003. Task-based language learning and teaching. Oxford: Oxford University Press. 
Graves, K. 2000. Designing language courses: A guide for teachers. Boston, MA: Heinle \& Heinle.

Greyling, A. 2014. Die ontwerp van 'n kursus vir Afrikaans vir spesifieke doeleindes vir eerstejaar-onderwysstudente binne die taakgebaseerde benadering. Ongepubliseerde Magistertesis. Stellenbosch: Universiteit Stellenbosch.

Jordan, R.R. 1997. English for academic purposes. Cambridge: Cambridge University Press.

Kikuchi, K. 2005. Student and teacher perceptions of learning needs: a cross analysis. Shiken: JALT Testing and Evaluation SIG newsletter 9(2): 8-20.

Klapper, J. 2003. Taking communication to task? A critical review of recent trends in language teaching. Language Learning Journal 27: 33-42.

Littlewood, W. 2004. The task-based approach: Some questions and suggestions. ELT Journal 58(4): 319-326.

Long, M.H. 2005. Second language needs analysis. Cambridge: Cambridge University Press.

Long, M.H. en Crookes, G. 1992. Three approaches to task-based syllabus design. Teaching English to speakers of other languages Quarterly 26(1): 27-56.

Minister van Onderwys. 2002. Language policy for Higher Education. Pretoria: Staatsdrukker. [Internet]. Beskikbaar: http://www.polity.org.za/article/language-policy-for-higher-educationnovember-2002-2002-11-15. (15 Julie 2011).

Minister van Onderwys. 2010. Draft policy on the minimum requirements for teacher education qualifications selected from the Higher Education Qualifications Framework (HEQF). Pretoria: Staatsdrukker. [Internet]. Beskikbaar: http://www.dhet.gov.za/LinkClick.aspx? fileticket=x/q3U3/0qSo=. (7 Junie 2013).

Nakao, K. 2011. Shogakko University English course: Needs analysis from the perspective of pre-service teachers. In A. Stewart (red.). JALT2010 Conference Proceedings. Tokyo: JALT. pp. 578-579.

Nunan, D. 2004. Task-based language teaching. Cambridge: Cambridge University Press.

Robinson, P. 1991. ESP today: A practitioner's guide. Prentice Hall: Prentice Hall International.

Samuda, V. en Bygate, M. 2008. Tasks in second language learning. Basingstoke: Palgrave Macmillan.

Skehan, P. 1998. A cognitive approach to language learning. Oxford: Oxford University Press.

Universiteit Stellenbosch. 2013. Jaarboek 2012: Deel 6. Stellenbosch: Universiteit Stellenbosch. pp. 71-74. 
Van der Walt, C. en Ruiters, J. 2011. Every teacher a language teacher? Developing awareness of multilingualism in teacher education. Journal for Language Teaching 45(2): 84-98.

Van Dyk, T.J. 2005. Towards providing effective academic literacy intervention. Per Linguam 21(2): 38-51.

Van Rensburg, C. en Weideman, A.J. 2002. Language proficiency: Current strategies, future remedies. SAALT Journal for Language Teaching 36(1\&2): 152-164.

West, R. 1994. Needs analysis in language teaching. Language Teaching 27(1):1-19. 